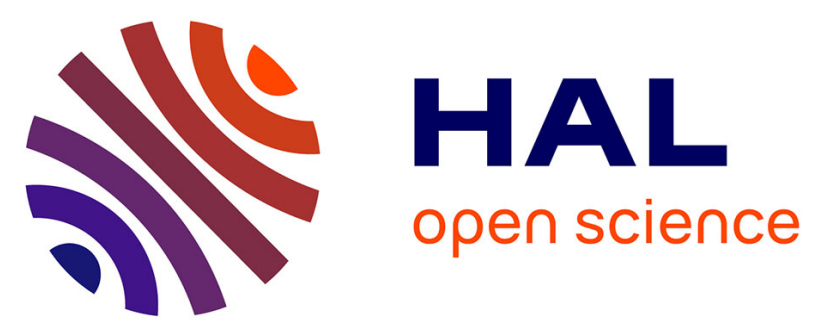

\title{
Multistage rifting evolution of the Colorado basin (offshore Argentina): Evidence for extensional settings prior to the South Atlantic opening
}

Juan Pablo Lovecchio, Sébastien Rohais, Philippe Joseph, Néstor Bolatti, Pedro Kress, Ricardo Gerster, Victor Ramos

\section{To cite this version:}

Juan Pablo Lovecchio, Sébastien Rohais, Philippe Joseph, Néstor Bolatti, Pedro Kress, et al.. Multistage rifting evolution of the Colorado basin (offshore Argentina): Evidence for extensional settings prior to the South Atlantic opening. Terra Nova, 2018, 30 (5), pp.359-368. 10.1111/ter.12351 . hal-01950210

\section{HAL Id: hal-01950210 \\ https://hal-ifp.archives-ouvertes.fr/hal-01950210}

Submitted on 10 Dec 2018

HAL is a multi-disciplinary open access archive for the deposit and dissemination of scientific research documents, whether they are published or not. The documents may come from teaching and research institutions in France or abroad, or from public or private research centers.
L'archive ouverte pluridisciplinaire HAL, est destinée au dépôt et à la diffusion de documents scientifiques de niveau recherche, publiés ou non, émanant des établissements d'enseignement et de recherche français ou étrangers, des laboratoires publics ou privés. 
Multistage rifting evolution of the Colorado basin (offshore Argentina): Evidence for extensional settings prior to the South Atlantic opening

\author{
7.1 Abstract \\ 7.2 Introduction \\ 7.3 Materials and Methods \\ 7.4 Results \\ 7.5 Discussion \\ 7.6 Conclusions
}




\subsection{Introduction}

Understanding the evolution of volcanic passive margins, especially the crustal architecture and related rifting mechanics, has been greatly enhanced thanks to high resolution and deep seismic data (Franke et al., 2006, 2007; Blaich et al., 2013;Stica et al., 2014) as well as to major advances in numerical modeling (Beniest et al., 2017; Geoffroy et al., 2015). However, most of the proposed models were built based on 2D cross sections, without considering the basement heterogeneities on either conjugate margin in a 3D perspective. Will and Frimmel (2018) analyzed the factors conditioning the emplacement of the South Atlantic Ocean focusing on intrinsic basement heterogeneities associated with the Neoproterozoic Brasiliano-Panafrican orogeny, disregarding other heterogeneities introduced by previous rifting events.

The opening of the South Atlantic in the Early Cretaceous was only the final stage of a complex rifting process (Uliana et al., 1989) that initiated after the Mid-Permian to EarlyTriassic Gondwanan orogeny (Hälbich, 1983; Hansma et al., 2016). The Central Atlantic was the locus of the Triassic rifting. Intracontinental rifts also developed in Africa and South America at this time (Zerfass et al., 2004). The Karoo rifting on Eastern Africa since the Early Jurassic (Delvaux, 2001), is associated with breakup of Africa from Antarctica and India and the opening of the Weddell Sea (Ghidella et al., 2002). In the Early Cretaceous E-W directed extension is responsible for the South Atlantic opening. Frizon De Lamotte et al. (2015) review rifting processes in the Pangea breakup and suggest that, oppositely to the active Karoo rifting, the Early Cretaceous rifting (responsible for the opening the South Atlantic) was passive rifting, related to far-field forces controlling the initiation of rifting diachronically from south to north (Nürnberg and Müller, 1991).

On the Argentinean South Atlantic margin, prerift is composed of Late Paleozoic glacial and marine successions that were involved in a Permian-Early Triassic Ventania-Cape fold belt (Pángaro and Ramos, 2012; Pángaro et al., 2016), which has been traced across the South Atlantic to the Namibian margin (Paton et al., 2016).

The Colorado and the Salado basins (Fig 4.1) are troughs oriented largely E-W, at high angle with the NNE-oriented continent-ocean boundary (COB). Magma-rich rifted margins as the southern South Atlantic are characterized by the presence of SDRs (Seaward Dipping Reflectors; Hinz, 1981; Gladczenko et al., 1997; Hinz et al., 1999; Stica et al., 2014; and Paton 
et al., 2017) on the continent-ocean transition (COT). We define the COT as the area with SDR development on thinned transitional crust (sensu Blaich et al., 2013). The external boundary of the COT, passing to the normal oceanic crust domain is the continent-ocean boundary (COB in Fig. 4.1).

The chronology of rifting in the Colorado and Salado basins is poorly constrained. Hydrocarbon exploration wells were drilled on structural highs outside the main depocenters and the few wells that investigated the synrift section mostly found red beds, where datable fossils are scarce.

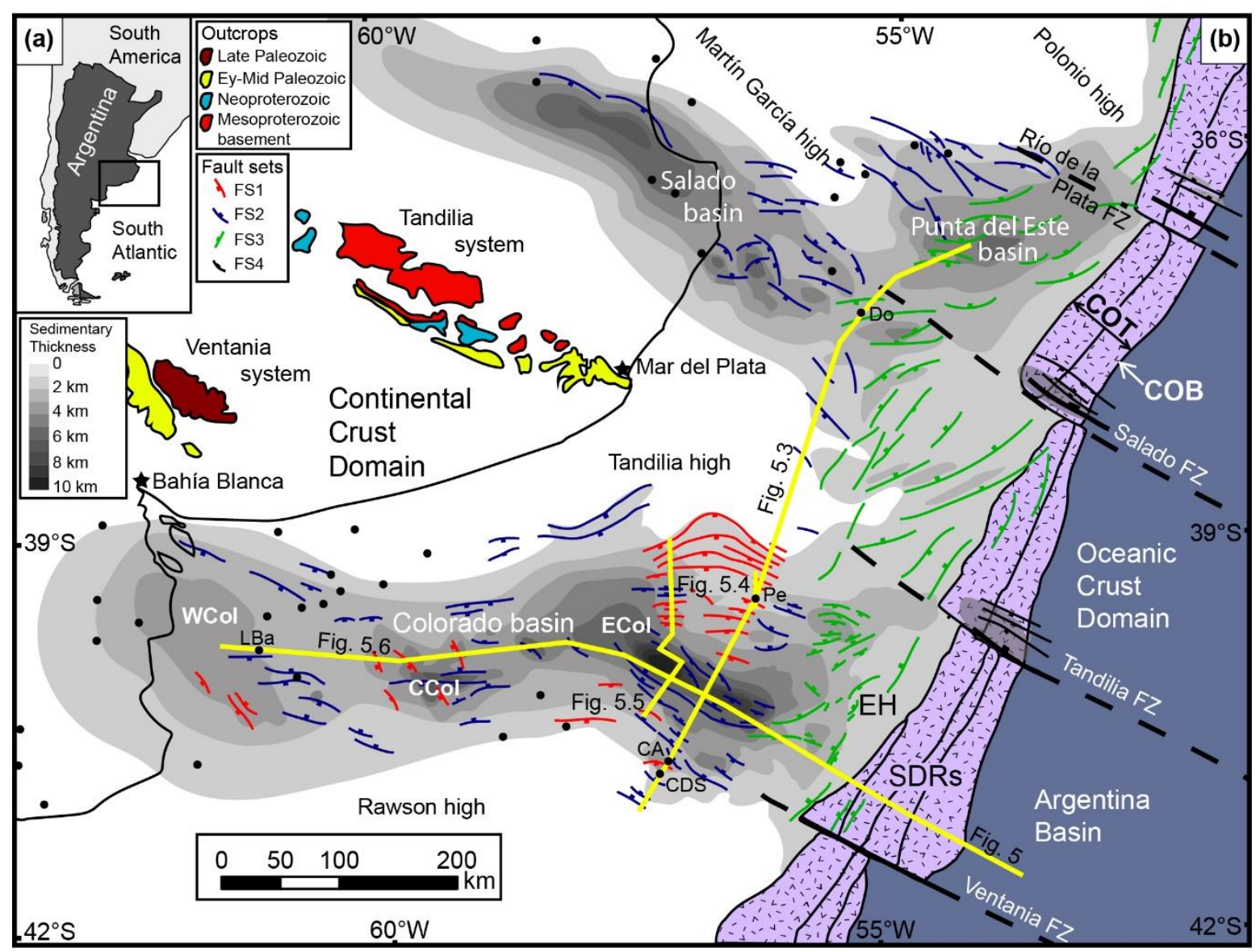

Figure 4.1: Structural map of the Colorado and Salado basins (offshore Argentina) and the Punta del Este basin (offshore Uruguay). A: Map showing the location of the study area. B:

Total sedimentary thickness on the continental crust domain (CCD). Colorado basin depocenters: WCol (western), CCol (central), ECol (eastern). Faults have been gathered into four fault sets (FS) according to their relative chronology. SDR wedges (mapped after Franke et al., 2007; and Soto et al., 2011). COT: continent-ocean transition, COB: cont-ocean boundary, OCD: Oceanic crust domain, FZ: fracture zone, EH: External High. The black dots show the location of the exploration wells. Yellow lines indicate the location of seismic transects presented in this contribution. 
Several hypotheses were proposed to explain the high obliquity between these basins and the NNE-oriented COB. At first, studies implied the development of both basins synchronously leading to the opening of the South Atlantic in a single and continuous rifting event. Obliquity was explained either by aulacogens (Yrigoyen, 1975, Introcaso and Ramos, 1984) controlled by Paleozoic or previous sutures (Ramos, 1996), transtensional basins associated with NW-SE dextral shear systems (Keeley and Light, 1993; Tankard et al., 2009; Franke et al., 2006), or as due to structural inheritance (Urien et al., 1995; Dominguez et al., 2011; Gebhard, 2005).

More recently, two superimposed rifting stages were used to explain the obliquity: a first Jurassic event with a NE-SW oriented extension, forming the Colorado and Salado basins, and a second E-W oriented extensional event forming the South Atlantic rift in the Early Cretaceous (Macdonald et al., 2003; Gerster et al., 2011; Pángaro and Ramos, 2012; Autin et al., 2013; Franke, 2013).

In this paper, after having carried out seismic interpretation and identified cross-cutting relationships between different generations of faults, we present evidence for not only two but three independent extensional stages. An older, previously unknown event was identified in the study area. This event is evidenced by the extensional reactivation of previously compressive thrusts of the Ventania-Cape fold belt. Extensional reactivation of thrusts has been described in other locations in Gondwana (De Wit and Ransome, 1992; Aldiss and Edwards, 1999; Franzese and Spalletti, 2001; Paton, 2006).

\subsection{Materials and Methods}

The database made available by YPF SA comprised 25 exploration wells (Fig. 4.1) and more than $30,000 \mathrm{~km}$ of 2D multichannel reflection PSTM seismic lines in the Colorado and Salado basins. Petrel software was used for interpretation. Time structure maps were generated for selected horizons (Fig. 4.2) to delineate the main depocenters. Wells were tied to seismic lines using synthetic logs or VSP data when available, producing new velocity laws that were integrated into a 3D regional velocity model used to convert the time structure maps and 2D TWT seismic sections into depth. Faults were interpreted on seismic lines and a structural model was prepared. Faults were then grouped into sets according to their orientation, dip, displaced reflectors, detachment level and cross-cutting relationships. 


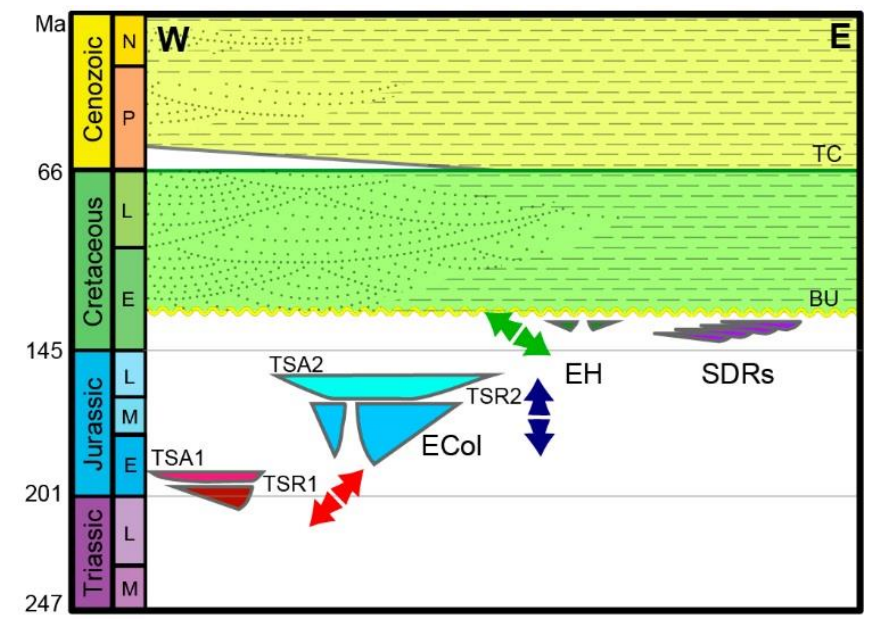

Figure 4.2: Schematic chronostratigraphic chart depicting chronology of rifting events and the main horizons used in seismic interpretation. TSR1: Top Synrift 1, TSA1: Top Sag 1, TSR2: Top Synrift 2, TSA2: Top Sag 2, BU: Breakup Unconformity, TC: Top Cretaceous. Arrows indicate the main direction of extension for each rifting stage (respect to present day South America). Late Triassic-Early Jurassic rifting (FS1): SW-NE extension; Early-Mid Jurassic rifting (FS2): N-S extension; Early Cretaceous rifging (FS3) and SDR emplacement: WNWESE extension.

\subsection{Results}

A structural map of the Colorado and Salado basins is presented in figure 4.1. The deepest Eastern Colorado (ECol) depocenter is a half-graben controlled by a NW-striking, NEdipping master fault (Figs. 4.3, 4.5 and 4.6). In a structural section across ECol (Fig. 4.3) two sets of faults were identified. Tilted blocks on the northern flank of ECol are associated with a first set of faults (FS1), dipping to the S-SW and detaching at a level within the crust (at depths of approximately 10-15 km. Paleozoic strata are preserved in the tilted blocks but the synrift deposits associated with the rotation of these blocks are mostly eroded (Fig. 4.4, Pángaro and Ramos, 2012). 

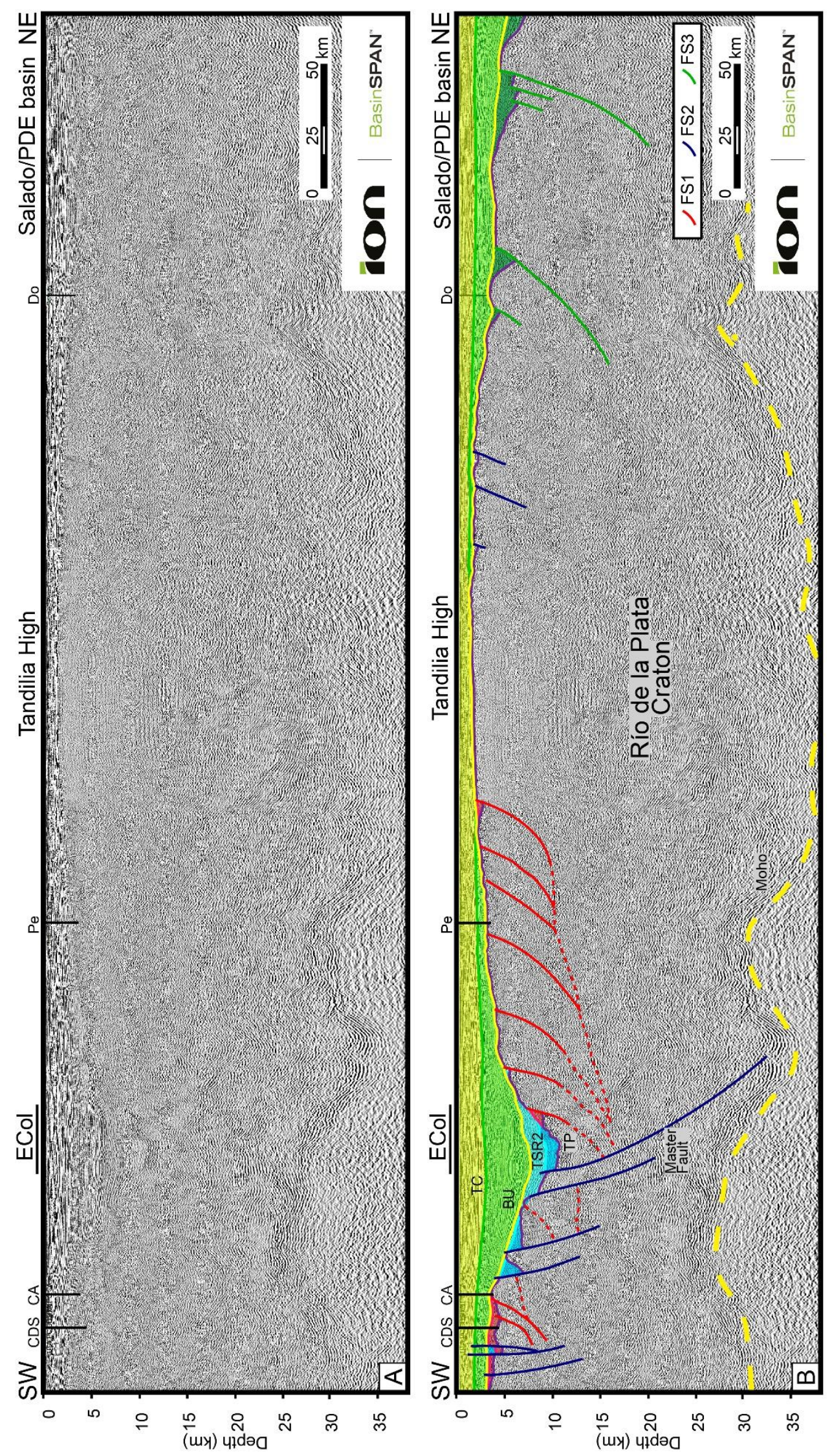

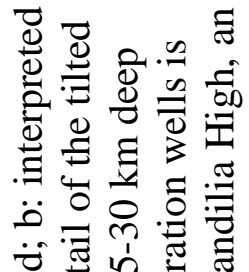

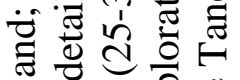

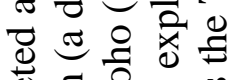

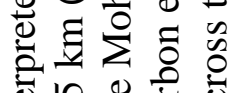

ฮ의

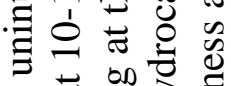

주

$\ddot{\circ} .0$ 。

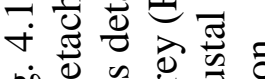

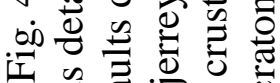

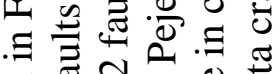

ฮี

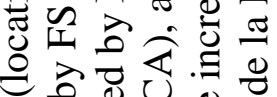

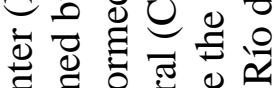

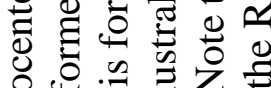

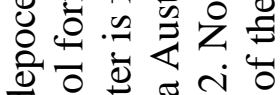

过完离

ن

当完.

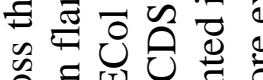

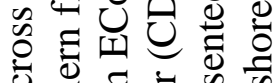

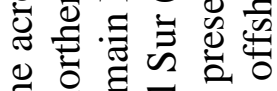

$\Xi \underset{0}{\Xi} \cong$

.르를

.

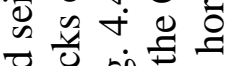

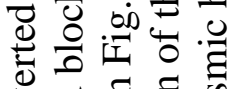

홇.

洁 䒕

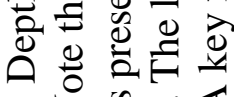

$\ddot{n} \dot{\sim} \mathscr{\sim}$

サे

可 

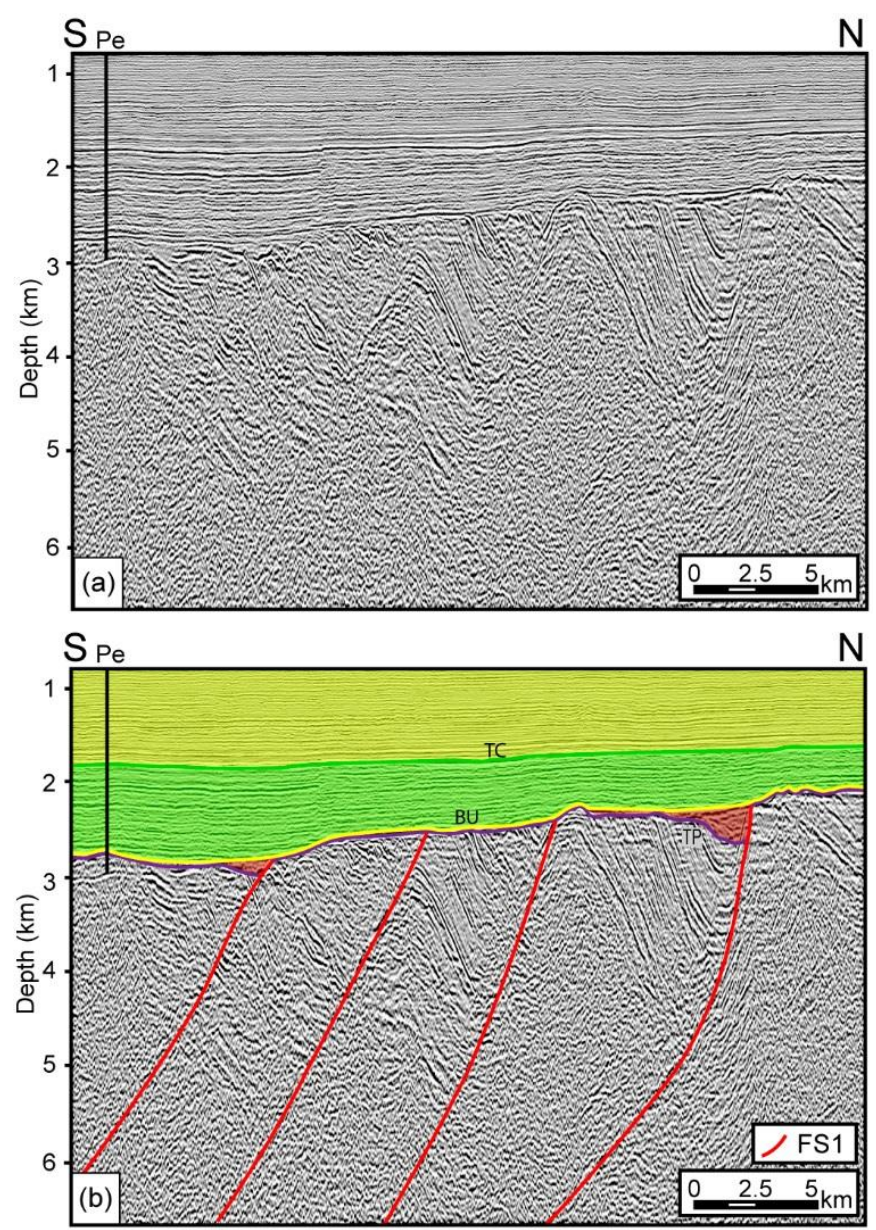

Figure 4.4: Depth converted seismic line on the northern flank of the ECol depocenter. A: uninterpreted and, B: interpreted section. Tilted blocks associated with FS1 faults are shown in detail. Note that most of the synrift associated with this rifting has not been preserved. The location of the Pejerrey (Pe) well is shown.

A second set of faults (FS2), including the master fault forming ECol and conjugates, intersects FS1 faults. FS2 faults are steeper and more deeply rooted, with the master fault possibly detaching at deep crustal levels close to the Moho (at a depth of about $30 \mathrm{~km}$, Fig. 4.3). By extrapolating these observations across the study area, we classified the observed faults into four fault sets according to their relative chronology. Besides FS1 and FS2 already presented, FS3 faults are largely oriented NNE parallel to the SDRs and continent-ocean boundary and restricted to the outer 100-200 km of the continental crust domain and COT (Fig. 4.1 and 4.6). Finally, FS4 faults were interpreted in the areas affected by fracture zones. Although the fracture zones appear to have an impact on the shelf structure and onshore geology, FS4 faults are restricted to the COT affecting SDRs wedges (Fig. 4.1). 

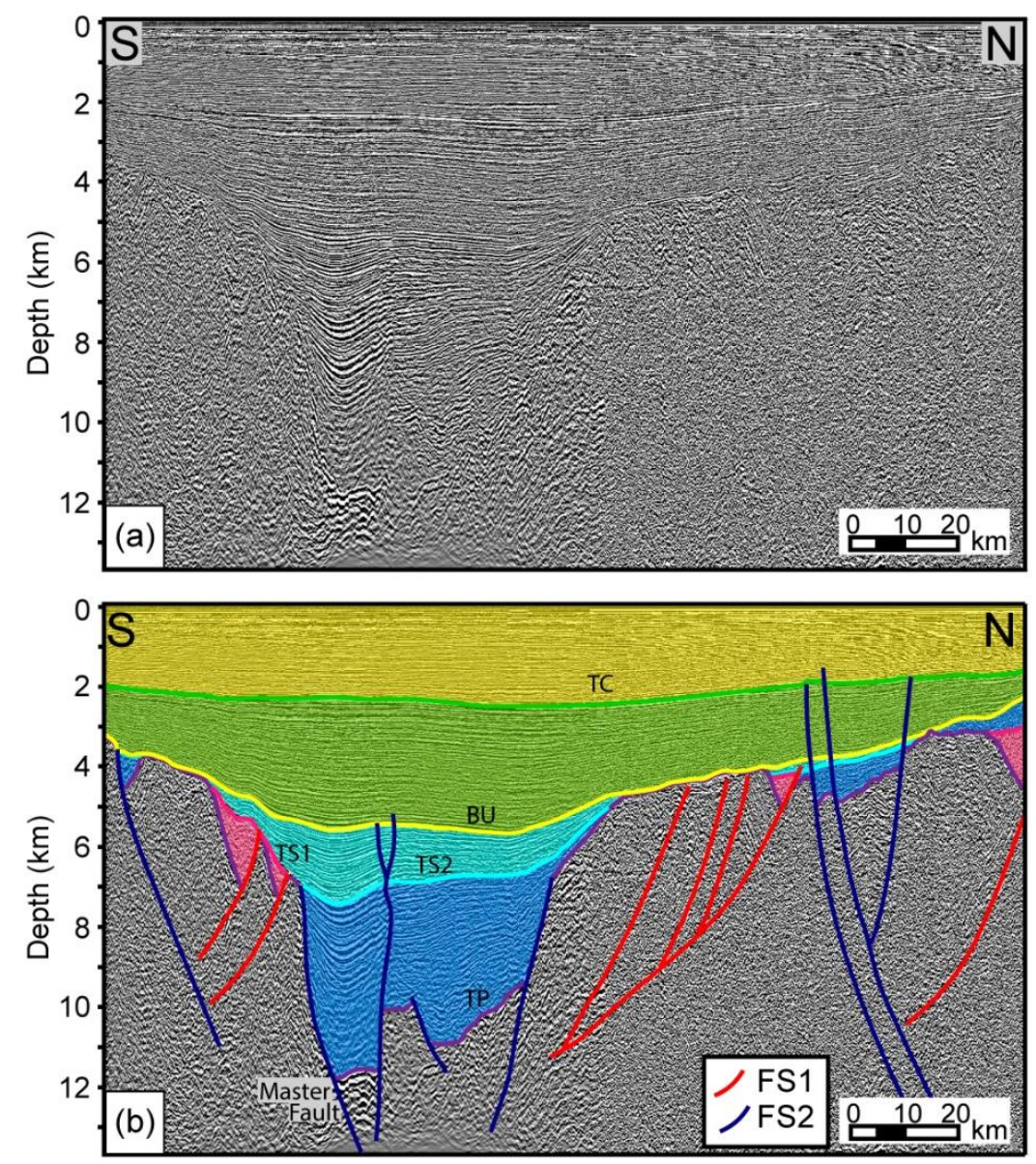

Figure 4.5: Depth converted seismic transect across the ECol depocenter. A: uninterpreted and, B: interpreted transect. Note preserved half-grabens of rifting stage 1 on the southern flank of ECol and transection of FS1 and FS2 faults.

On another seismic transect across ECol, tilted blocks were identified both on the northern and the southern flank of the depocenter, forming relict half-grabens 'hanging' on the footwall of the ECol master fault (Fig. 4.5). Some FS2 faults show reactivation reaching the top Cretaceous horizon, probably associated with strike-slip movement during the drifting phase. FS1 faults do not present Late Cretaceous reactivation. 

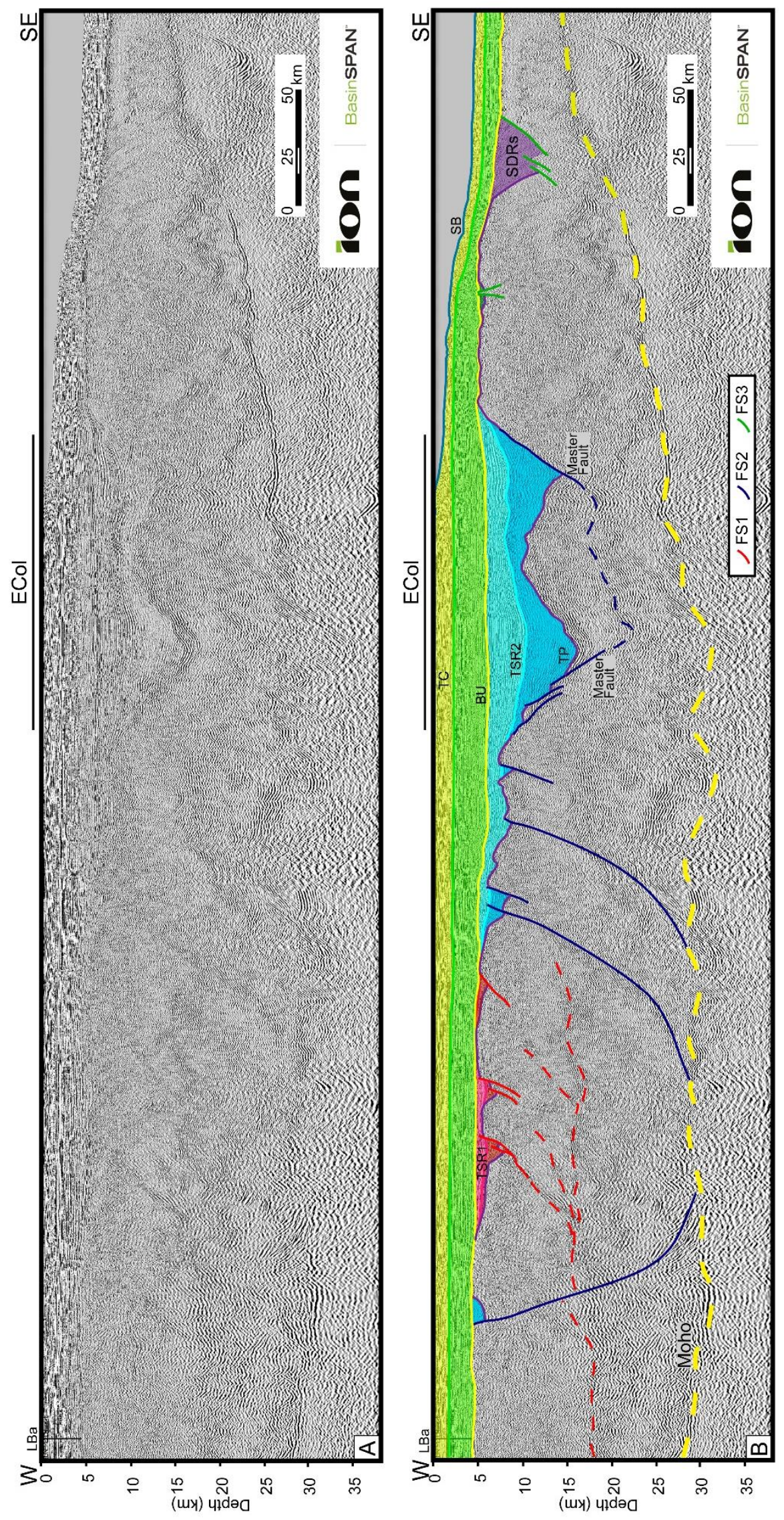

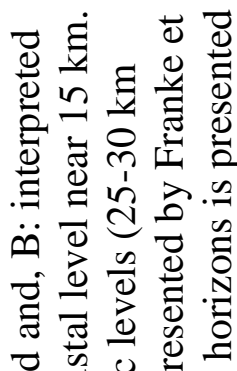

马을.

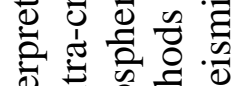

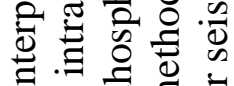

完: 它

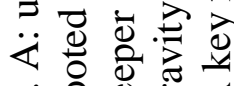

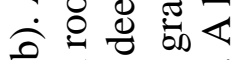

ㄷ छ

is

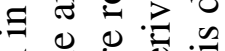

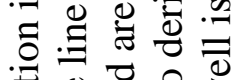

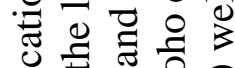

윤

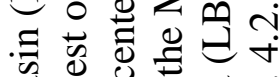

ส 3 \&

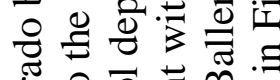

훙워

잉

\&

ज 5000

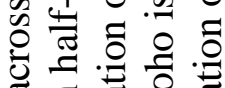

ช छ

Ð $\Xi \sum_{0} 0$

.르류

悉昰

ठ더웡

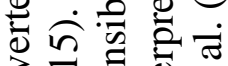

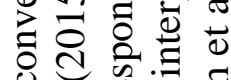

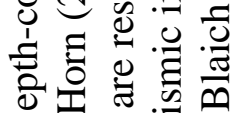

닌

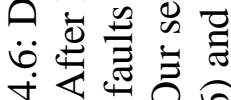

†

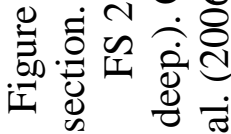


In the central area, north of the CCol depocenter, a set of NNW-striking listric faults forming tilted blocks and half-grabens, with an intra-crustal detachment level (approx. 17-20 km deep, Fig. 4.6) are intersected by the E-W-oriented, S-dipping, master fault forming the Central Colorado half-graben (CCol, see Fig. 4.1 for location, $\mathrm{CCol}$ spans south of the seismic line presented on Fig. 4.6). Similarly to the he ECol-master fault, the CCol-master fault presents a steep geometry and detachment at a deep lithospheric level $(\sim 25 \mathrm{~km})$.

Thick synrift seismic sequences (fault-bounded wedges with divergent reflectors towards the active fault) were interpreted for the Central and Eastern depocenters. Data quality in WCol did not allow synrift interpretation. A postrift package (reflectors passively onlapping the basement highs around the depocenters beyond the synrift-bounding faults) was also interpreted. In passive margin-related basins, the synrift-to-postrift unconformity typically marks the breakup event (Franke, 2013). The breakup unconformity (BU in Fig. 4.2) marks the onset of oceanic crust accretion and is interpreted in volcanic margins at the top of SDR wedges (Fig. 4.6). In the Colorado basin, however, a postrift package was identified between the top of the synrift (TSR2) and the breakup unconformity, tracked from the COT domain (Fig. 4.6).

The NE-NNE striking faults of FS3 are restricted to a strip covering the easternmost 100-200 km of the continental crust domain. They form half-grabens on the northern flank of the Tandilia high and are responsible for structuring the external high (EH), a block formed of continental crust that separates the ECol depocenter from the COT-SDR domain (Franke et al., 2006; Gerster et al., 2011; Fig. 4.1). For depocenters formed by FS3 faults, the BU is indeed the synrift-postrift unconformity (sensu Franke, 2013). Therefore we interpret this extensive event as being part of the South Atlantic opening and largely contemporaneous with the emplacement of SDRs further east (sensu Stica et al., 2014). FS3 faults may present extensional reactivation across the $\mathrm{BU}$ indicating extensional activity during and slightly after the breakup.

\subsection{Discussion}

Based on the data analyzed, and by integrating the relative chronology of faulting within the regional tectonic framework, we propose a model for basin evolution with three rifting stages (Fig. 4.7).

The final stage, Early Cretaceous rifting, is the best constrained in age as it is directly associated with SDR emplacement and breakup. Neither the SDRs nor the oceanic crust have 
been drilled in this part of the South Atlantic. Plate kinematic models are useful to integrate data on both margins and are calibrated with oceanic crust magnetic anomalies (Moulin et al., 2010; Heine et al., 2013). SDRs have been drilled however, on the conjugate Namibian margin (Kudu well) and sedimentary packages interbedded with the volcanics were dated Barremian (McMillan, 1990). Faults grouped in FS3 are subparallel to the SDR wedges bounding reflectors and the COB and are restricted to the outer 100-200 km wide fringe of the continental crust domain (Fig. 4.7c). We interpret FS3 as genetically linked to the Early Cretaceous rifting stage, and their development in a narrow fringe as due to a concentration of strain around the incipient ridge. FS4 faults also developed as part of the Early Cretaceous rifting event, but associated with margin segmentation during SDR emplacement (see Franke, 2013).

However, the main rifting event for the area of study is older and is associated with FS2 faults forming the ECol and CCol depocenters in Colorado, and the adjacent Salado basins (Fig. 4.7b). From the presence of a thick postrift unit preserved in ECol (between TSR2 and BU, Fig. 4.2), we infer that thermal subsidence had already started before the Early Cretaceous breakup, confirming at least two independent rifting settings. We interpret Early-to-Mid Jurassic, largely oriented N-S extension for this event and correlate it with the Karoo rifting.

Cross cutting of FS1 faults by FS2 faults identified in the ECol and CCol depocenters point to the presence of a previously unknown rifting stage. We associate the NW-striking, SSW dipping listric faults with the extensional reactivation of thrusts of the Permian to Early Triassic Ventania-Cape fold belt. Seven of these former thrusts were identified in the study area (Fig. 4.7a). Figure 4.8 is a seismic transect across the former Ventania-Cape fold belt in the Colorado basin area, formed by a combination of the seismic lines presented in figures 4.6 and 4.3. The detachment for FS1 faults follows the detachment of the former thrusts and shallows towards the NE, away from the Gondwanides orogen ( Mosquera et al., 2011). Note the transection of the extensionally reactivated thrusts (FS1) with the master fault forming ECol (FS2) in the central area. A Late Triassic-Early Jurassic age for this initial rifting stage is interpreted by association with the Precuyano rifting event in the Neuquén basin (D'Elia et al., 2015) that has also been related to reactivation of Late Paleozoic structures (Mosquera and Ramos, 2006). FS1 faults do not seem to be present in the Salado basin area as this region was north of the area of influence or the Permian-Early Triassic Ventania-Cape fold belt. 


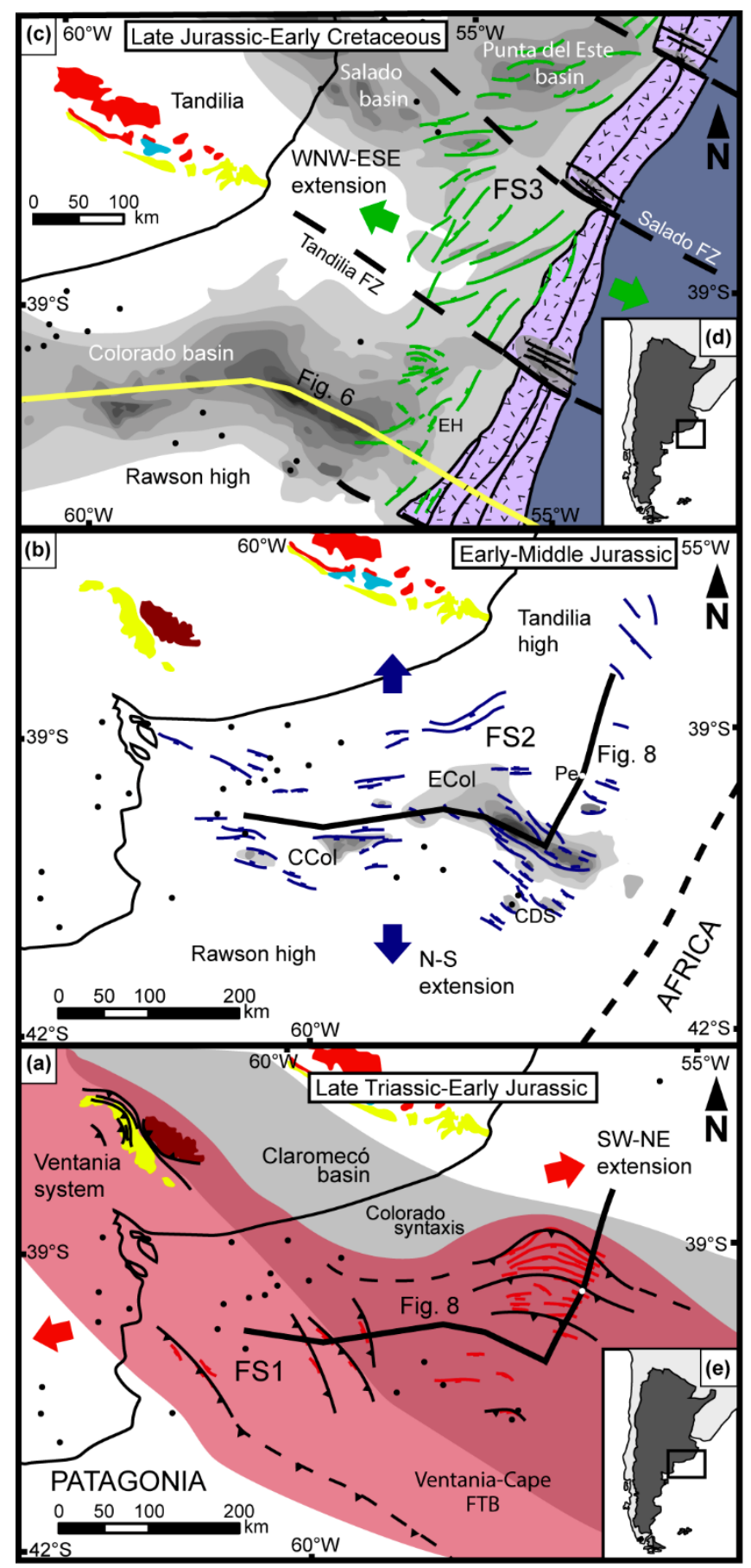

Figure 4.7: Tectonic evolution of the Colorado basin: a) Late Triassic-Early Jurassic rifting stage associated with FS1 faults, extensionally reactivated thrusts of the Late Permian-Early Triassic Ventania-Cape fold belt. Main reactivated thrusts are drawn in black; b) Main rifting stage (Early-Mid Jurassic) responsible for FS2 faults and the formation of the Colorado and Salado basins' main depocenters; c) Final rifting stage (Early Cretaceous) related to the South Atlantic breakup and emplacement of SDRs. FS3 faults are largely oriented NNE, parallel to the SDRs and COB; d) Location map for Fig. 4.7c; e) Location map for Fig. 4.7a and b. 

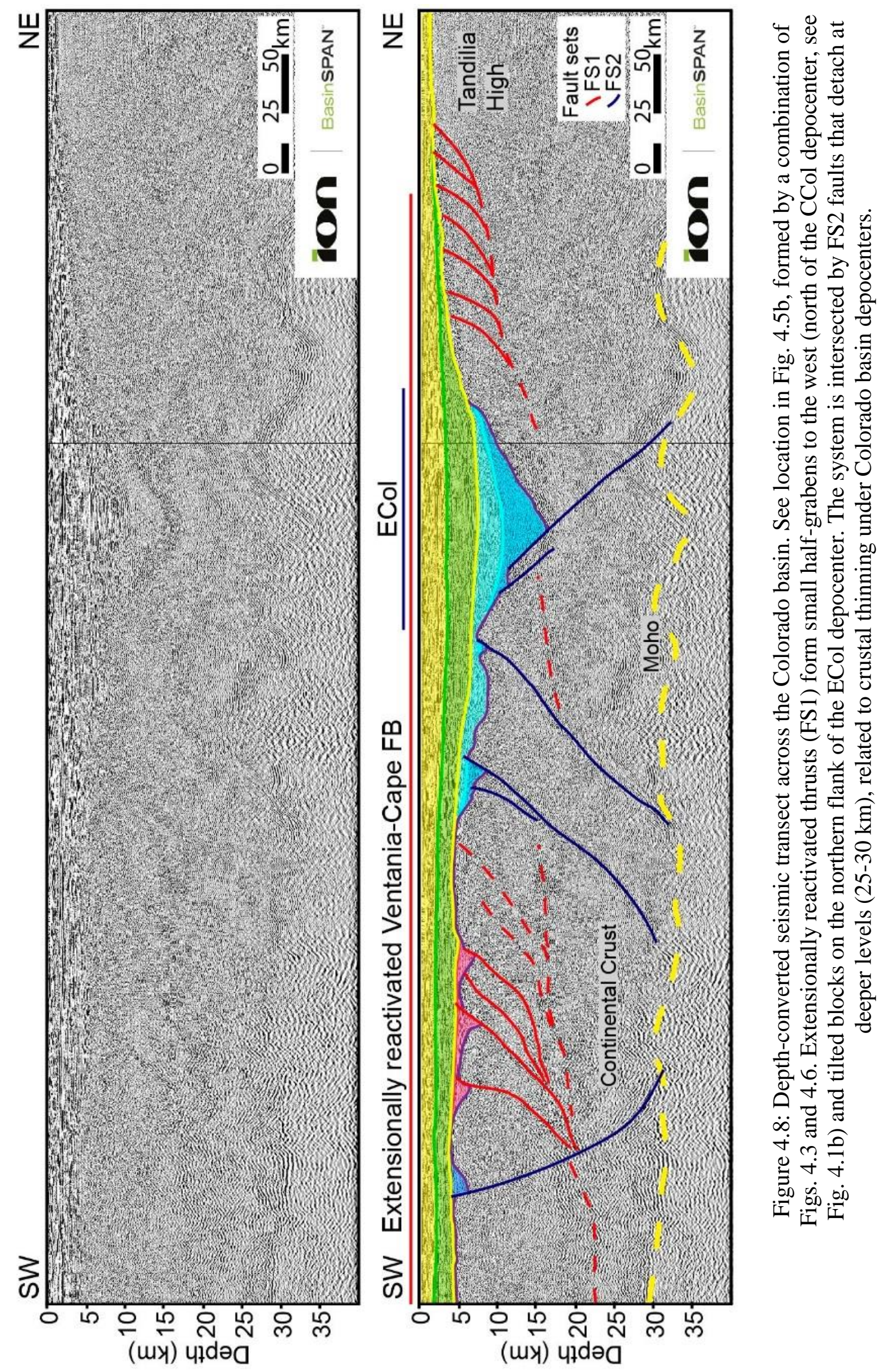
The understanding of the complex rifting history of the southern South Atlantic segment is crucial to better model the conjugate margins. Most 2D models consider the Colorado main rifting even (Early-Mid Jurassic) as synchronous with SDR emplacement and the South Atlantic opening. We showed that it is not the case. Crustal thinning in the Colorado basin is oriented E-W, as a consequence of the Early-Mid Jurassic rifting related to N-S extension. Models attempting to explain this 3D complexity with a single event on 2D sections oversimplify the Gondwana breakup history along the Argentinean margin.

\subsection{Conclusions}

The identification of three rifting stages in the Colorado basin is key to understanding the complexity of long term continental breakup processes that affected the Paleozoic supercontinents. A previously unknown rifting stage was identified. Extensional reactivation of Late Paleozoic-Early Triassic thrusts of the Ventania-Cape Fold Belt was produced in Late Triassic-Early Jurassic times. A second rifting stage was responsible for the main depocenters of the Colorado and Salado basins. Faults associated with this stage cross cut older faults and are largely oriented E-W to SE-NW. An Early-Mid Jurassic age was assigned to this stage, in agreement with the Karoo rifting and the N-S extension responsible that ended with the opening of the Weddell Sea. The area went into a final rifting stage in the Latest Jurassic-Early Cretaceous. With extension oriented WNW-ESE, faults developed in the outer 100-200 km wide fringe parallel to the NNE-striking COB. This final rifting stage involved the emplacement of SDRs and produced the opening of the South Atlantic Ocean. 